\title{
DERAJAD EOSINOFILIA PADA PENDERITA INFEKSI SOIL-TRANSMITTED HELMINTH (STH)
}

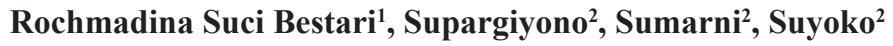 \\ ${ }^{1}$ Program Magister Studi Ilmu Kedokteran Dasar \& Biomedis Minat Parasitologi \\ Fakultas Kedokteran Universitas Gadjah Mada \\ ${ }^{2}$ Bagian Parasitologi FakultasKedokteran Universitas Gadjah Mada \\ Korespondensi: Rochmadina Suci Bestari \\ Email: rochmadina@gmail.com
}

\begin{abstract}
ABSTRAK
Soil-Transmitted Helminth (STH) menginfeksi lebih dari satu milyar orang di seluruh dunia. Di Indonesia, prevalensi STH di beberapa tempat juga masih tinggi, ada diantaranya dengan prevalensi 40-60\% pada semua umur, dengan jenis cacing dan intensitas yang berbeda-beda. Masyarakat yang tinggal di sekitar Tempat Pembuangan sampah Akhir (TPA) biasanya sanitasinya buruk. Beberapa data menunjukkan bahwa pada penderita dengan infeksi STH sering menunjukkan gejala alergi seperti gatal-gatal pada kulit dan batuk kronis. Penelitian ini dilaksanakan untuk mengetahui hubungan infeksi STH dengan angka eosinofil pada masyarakat di sekitar TPA Kelurahan Mojosongo Kecamatan Jebres Kota Surakarta, Jawa Tengah, Indonesia. Sampel tinja dan darah dikoleksi dari 96 warga yang bersedia berpartisipasi (dengan informed consent). Metode Kato-Katz digunakan untuk mengetahui adanya infeksi STH dan mengetahui intensitas infeksinya. Hitung eosinofil dilakukan pada sediaan apus darah tipis yang dipulas dengan Giemsa untuk mengetahui persentase eosinofil pada penderita. Prevalensi infeksi STH secara keseluruhan sebesar 7,29\% (7/96) dengan rata-rata jumlah telur 61 telur per gram feses. Semua menderita infeksi tunggal dan tidak ada yang infeksi campuran. Infeksi hookworm sebesar 6,25\% (6/96) dan infeksi Trichuris trichiura sebesar 1,04\% (1/96). Tidak ditemukan infeksi Ascaris lumbricoides. Semuanya menderita infeksi ringan. Prevalensi eosinofilia adalah 27,8\% (26/96) dengan rata-rata persentase eosinofil 2,63\%. Terdapat hubungan yang signifikan antara intensitas infeksi STH dengan angka eosinofil, dengan kekuatan sangat lemah $(r=0,190 ; p=0,032)$.
\end{abstract}

Kata kunci : infeksi STH, intensitas infeksi STH, angka eosinofil, Kato-Katz, eosinofilia

\begin{abstract}
Soil-Transmitted Helminth (STH) infected more than one million people all over the world. In Indonesia, the prevalence of STH infection is still high in a few places, some of them are 40-60\% of all ages, with different species of helminth and intensity. Citizens around landfills usually has bad sanitary living. Some data showed that patients with STH infection often have alergic symptoms, like itchy on the skin and chronic cough. This research was held to know the relationship between STH infection and eosinophil score at citizens around landfills of Kelurahan Mojosongo Kecamatan Jebres Kota Surakarta, Central Java, Indonesia. Stool and blood sample from 96 citizens who agreed to participate (by informed consent) were collected. Kato-Katz method was used to determine the helminths intensity. Eosinophil count was used on thin blood smear staining by Giemsa to identify the percentage of eosinophil on the subjects. Prevalence of STH infection was 7,29\% (7/96) with egg density of 61 Egg Per Gram Feses (EPGF). Single type of helminth infection occured among the participants and there was no co-infection. Hookworm infection was 6,25\% (6/96) and Trichuris trichiura infection was 1,04\% (1/96). There was no Ascaris lumbricoides infection. All of them were light infection. The prevalence of eosinophilia was 27,8\% (26/96) with 2,63\% emean osinophil percentage. There was a very weak association between STH infection intensity and eosinophil score $(r=0,190 ; p=0,032)$. There was a very weak association between STH infection intensity and eosinophil score ( $r=0,190 ; p=0,032)$.
\end{abstract}

Keywords : STH infection, STH infection intensity, eosinophil score, Kato-Katz, eosinophilia 


\section{PENDAHULUAN}

Soil-Transmitted

Helminth

(STH)

menginfeksi lebih dari satu milyar orang di area tropis dan subtropis di seluruh dunia (Crompton dan Peters, 2010). Di beberapa tempat di Indonesia, prevalensi STH masih tinggi, antara 40-60 \% pada semua umur, dengan jenis dan intensitas yang berbeda-beda (Depkes RI, 2006). STH yang sering didapat di Indonesia terdiri dari tiga macam, yaitu Ascaris lumbricoides, hookworm dan Trichuris trichiura (Rusmartini, 2009). Diagnosis ketiganya bisa ditegakkan dengan ditemukannya telur cacing sesuai ciri khasnya dalam tinja, salah satunya dengan metode Kato-Katz. Metode ini juga dapat digunakan untuk mengklasifikasikan intensitas infeksi STHdalam beberapa tingkatan, yaitu ringan, sedang dan berat. Klasifikasinya berbeda untuk setiap jenis cacing (Depkes RI, 2006). Diagnosis dapat pula dibantu pemeriksaan darah dengan ditemukannya eosinofilia (Supali et al., 2011). Eosinofilia, sebagai marker respon sel Th2, dapat digunakan untuk menilai infeksi cacing (Janeway, 2005). Eosinofilia juga timbul pada beberapa gangguan non-STH, seperti wheezing, rhinitis, ekzema, konsumsi obat-obatan antibiotik (Ehrhardt dan Burchard, 2008; Rothenberg dan Epstein, 1998). Penelitian ini dilaksanakan untuk mengetahui hubungan infeksi STH dengan angka eosinofil pada masyarakat di sekitar Tempat Pembuangan Akhir Sampah (TPA) Kelurahan Mojosongo Kecamatan Jebres Kota Surakarta, Jawa Tengah, Indonesia. Masyarakat yang tinggal di sekitar Tempat Pembuangan sampah Akhir (TPA) biasanya sanitasinya buruk.

\section{METODE}

\section{Subyek penelitian}

Penelitian ini termasuk penelitian observasional analitik, dengan rancangan crosssectional. Penelitian dilakukan pada masyarakat RW 30 Kelurahan Mojosongo, Kecamatan Jebres, Kota Surakarta. Wilayahnya dekat dengan TPA Putri Cempa, Surakarta. Sebagian besar penduduknya bekerja sebagai pemulung. Dari penelitian pendahuluan pada empat warga, semuanya menderita infeksi STH. Dua dari mereka menderita infeksi campuran sedangkan dua yang lain menderita infeksi tunggal. Besar sampel sebanyak 96 warga, dihitung menggunakan cara penghitungan sampel oleh Lwanga dan Lemeshow (1991) dengan rumus :

$$
N=\frac{1,96^{2} \times 0,5 \times 0,5}{0,1^{2}}
$$

Sejumlah 96 sampel tersebut diambil dari 800 warga RW 30 yang diacak menggunakan program komputer.

\section{Pengumpulan Data}

Setelah mengambil informed consent dan mendapat pengesahan ethical clearance, 96 warga dikumpulkan dan diambil sampel darahnya.Sampel darah diambil dari darah perifer jari tangan, kemudian darah dibuat apusan dan diwarnai dengan pewarna Giemsa. Apusan diperiksa di bawah mikroskop dan dihitung persentase eosinofil.

Saat dikumpulkan, warga diberi pot tinja yang telah diberi formalin $4 \%$, pot tinja dibawa pulang, warga diminta mengisinya dengan tinja sendiri lalu dibawa ke rumah bapak RT masingmasing. Sampel tinja diambil peneliti untuk diperiksa di Laboratorium Parasitologi Fakultas Kedokteran UGM Yogyakarta.

Pemeriksaan tinja menggunakan Metode Kato-Katz untuk mengetahui adanya infeksi STH dan mengetahui intensitas infeksinya. Tinja diaduk agar homogen kemudian diletakkan sebanyak 5 gram di atas kertas minyak. Kawat kassa diletakkan di atas tinja tersebut lalu ditekan sehingga tinja akan tersaring melalui kawat kassa. Karton berlubang diletakkan di atas gelas benda, tinja yang telah disaring itu dicetak sebesar lubang karton. Berat tinja yang dicetak dapat diketahui lalu ditutup dengan pita selopan yang sebelumnya direndam dalam larutan glycerol-malachite greendalam waktu 24 jam. Sediaan ditekan dan diratakan kemudian dibiarkan dalam temperatur kamar minimal 30 menit agar transparan. Selanjutnya sediaan diperiksa di bawah mikroskop dengan pembesaran $4 \mathrm{x}$ kemudian 10x. Jumlah telur yang ditemukan dihitung untuk tiap jenis STH.

\section{Analisis Data}

Angka eosinofil dan Kato-Katz dicatat dalam skala rasio kemudian dianalisis hubungannya menggunakan Uji Korelasi Spearman. 
HASIL DAN PEMBAHASAN

Subyek penelitian adalah 96 warga RW 30 Kelurahan Mojosongo Kecamatan Jebres Kota
Surakarta yang mengumpulkan sampel tinja dan darah. Distribusi subyek penelitian disajikan pada Tabel 1.

Tabel 1. Distribusi subyek penelitian pada masyarakat di dekat TPA Kelurahan Mojosongo Kecamatan Jebres Kota Surakarta berdasarkan usia, jenis kelamin, tingkat pendidikan dan pekerjaan

\begin{tabular}{|c|c|c|c|}
\hline Karakteristik & & Jumlah & Persentase $(\%)$ \\
\hline \multirow[t]{8}{*}{ Usia (tahun) } & $6-10$ & 8 & 8,3 \\
\hline & $11-20$ & 8 & 8,3 \\
\hline & $21-30$ & 14 & 14,6 \\
\hline & $31-40$ & 27 & 28,2 \\
\hline & $41-50$ & 24 & 25 \\
\hline & $51-60$ & 7 & 7,3 \\
\hline & $61-70$ & 5 & 5,2 \\
\hline & $>70$ & 3 & 3,1 \\
\hline \multirow[t]{2}{*}{ Jenis kelamin } & Laki-laki & 40 & 41,7 \\
\hline & Perempuan & 56 & 58,3 \\
\hline \multirow[t]{6}{*}{ Tingkat pendidikan } & Tidak bersekolah & 11 & 11,5 \\
\hline & $\mathrm{TK}$ & 3 & 3,1 \\
\hline & SD & 35 & 36,5 \\
\hline & SMP & 25 & 26 \\
\hline & SMA & 20 & 20,8 \\
\hline & $\mathrm{D} 3 / \mathrm{S} 1$ & 2 & 2,1 \\
\hline \multirow[t]{8}{*}{ Pekerjaan } & Tidak bekerja & 14 & 14,5 \\
\hline & IRT & 3 & 3,1 \\
\hline & Swasta & 34 & 35,4 \\
\hline & Karyawan/buruh/PNS & 11 & 11,5 \\
\hline & Guru & 2 & 2,1 \\
\hline & Pelajar & 11 & 11,5 \\
\hline & Pedagang/wiraswasta & 5 & 5,2 \\
\hline & $\begin{array}{l}\text { Berhubungan dengan sampah/ } \\
\text { rosok/pemulung }\end{array}$ & 16 & 16,6 \\
\hline
\end{tabular}

Dari Tabel 1 dapat disimpulkan bahwa usia subyek penelitian berkisar antara 6 tahun hingga 80 tahun dengan jumlah yang bervariasi. Ratarata usia adalah 37,83 tahun (6-80 tahun). Dilihat dari jenis kelamin subyek penelitian, rasio subyek penelitian laki-laki : perempuan $=2: 3(40 / 56)$. Dari segi tingkat pendidikan, subyek penelitian paling banyak berpendidikan SD yaitu $36,5 \%$. Sedangkan pendidikan sarjana hanya 2,1\%. Dari segi pekerjaan, subyek penelitian paling banyak adalah swasta dan pekerjaan yang berhubungan dengan rosok.
Tabel 2. Hasil pemeriksaan tinja dari masyarakat di sekitar TPA Kelurahan Mojosongo Kecamatan Jebres Kota Surakarta

\begin{tabular}{lll}
\hline Jenis cacing & Jumlah & Persentase (\%) \\
\hline Ascaris lumbricoides & 0 & 0 \\
Hookworm & 6 & 6,25 \\
Trichuris trichiura & 1 & 1,04 \\
Tidak terinfeksi & 89 & 92,71 \\
\hline Total & 96 & 100
\end{tabular}


Dari Tabel 2 dapat dilihat bahwa prevalensi infeksi STH di RW 30 sebanyak 7,29\% (7/96) yang terdiri dari infeksi hookworm yaitu 6,25\% (6/96) dan infeksi T. trichiura sebanyak 1,04\% hanya satu subyek penelitian.
(1/96). Tidak ditemukan infeksi A. lumbricoides dan mixed infection. Pada penelitian ini, prevalensi infeksi hookworm lebih tinggi daripada infeksi $T$. trichiura. Infeksi T. trichiura sangat jarang, yaitu

Tabel 3. Distribusi infeksi STH pada masyarakat di sekitar TPA Kelurahan Mojosongo Kecamatan Jebres Kota Surakarta berdasarkan jenis kelamin, pekerjaan dan usia

\begin{tabular}{llcc}
\hline \multirow{2}{*}{ Kriteria } & \multicolumn{2}{c}{ Jenis STH } \\
\cline { 2 - 4 } Jenis kelamin & Laki-laki & $3(50 \%)$ & $0(0 \%)$ \\
& Perempuan & $3(50 \%)$ & $1(100 \%)$ \\
\multirow{3}{*}{ Pekerjaan } & $5(83,3 \%)$ & $0(0 \%)$ \\
\multirow{4}{*}{ Usia } & Pemulung & $1(16,7 \%)$ & $1(100 \%)$ \\
& Tidak bekerja & 0 & 0 \\
& $6-10$ & 0 & 0 \\
& $11-20$ & 2 & 0 \\
& $21-30$ & 0 & 1 \\
& $31-40$ & 1 & 0 \\
& $41-50$ & 1 & 0 \\
\hline
\end{tabular}

Dari Tabel 3 dapat disimpulkan bahwa subyek penelitian berjenis kelamin perempuan yang terinfeksi STH lebih banyak daripada lakilaki (4:3). Sebagian besar subyek penelitian yang menderita STH bermatapencaharian sebagai pemulung, yaitu sebesar 71,42\% (5/7). Usia dari subyek penelitian yang terinfeksi hookworm adalah 50\% (3/6) berusia 30-44 tahun sedangkan $50 \%(3 / 6)$ lainnya berusia $>50$ tahun. Subyek terinfeksi $T$. trichiura berusia 40 tahun.

Tabel 4. Intensitas infeksi STH pada masyarakat di sekitar TPA Kelurahan Mojosongo Kecamatan Jebres Kota Surakarta

\begin{tabular}{llll}
\hline Jenis STH & RTPG & Intensitas & Jumlah \\
\hline Hookworm & 33 & ringan & 3 \\
& 66 & ringan & 1 \\
& 99 & ringan & 1 \\
& 132 & ringan & 1 \\
Trichuris trichiura & 33 & ringan & 1 \\
\hline
\end{tabular}

Dari Tabel 4 didapatkan intensitas infeksi
STH ringan, baik pada infeksi hookworm maupun T. trichiura. Rata-ratanya 61 telur per gram tinja.

Tabel 5. Hasil pemeriksaan angka eosinofil pada masyarakat di sekitar TPA Kelurahan Mojosongo Kecamatan Jebres Kota Surakarta

\begin{tabular}{cccc}
\hline $\begin{array}{c}\text { Angka eosinofil } \\
(\%)\end{array}$ & $\begin{array}{c}\text { Tingkat } \\
\text { eosinofilia }\end{array}$ & $\begin{array}{c}\text { Jumlah } \\
\text { orang }\end{array}$ & $\begin{array}{c}\text { Persentase } \\
(\%)\end{array}$ \\
\hline $0 \%-3 \%$ & normal & 70 & 72,9 \\
$4 \%-6 \%$ & ringan & 24 & 25 \\
$7 \%-9 \%$ & sedang & 2 & 2,1 \\
$>9 \%$ & tinggi & 0 & 0 \\
\hline Total & & & 100
\end{tabular}

Dari Tabel 5 didapatkan eosinofilia $27,1 \%$ dan tidak eosinofilia sebanyak $72,9 \%$. Penelitian ini menggunakan penghitungan cara manual dari apus darah tepi. Untuk mengetahui kesepakatan kappa dengan pemeriksaan dari laboratorium profesional, peneliti membandingkan 10 sampel. Hasilnya kesepakatan kappa sebesar 0,44 . 
Tabel 6. Hubungan antara infeksi STH dengan eosinofilia pada masyarakat di sekitar TPA Kelurahan Mojosongo Kecamatan Jebres Kota Surakarta

\begin{tabular}{llcccc}
\hline \multirow{2}{*}{ Infeksi STH } & \multirow{2}{*}{ Intensitas } & \multicolumn{4}{c}{ Tingkat eosinofilia } \\
\cline { 3 - 6 } & & $0-3 \%$ & $4-6 \%$ & $7-9 \%$ & $>9 \%$ \\
\cline { 3 - 6 } Hookworm & ringan & 3 & 3 & 0 & 0 \\
& sedang & 0 & 0 & 0 & 0 \\
& berat & 0 & 0 & 0 & 0 \\
\multirow{3}{*}{ Trichuris trichiura } & ringan & 0 & 1 & 0 & 0 \\
& sedang & 0 & 0 & 0 & 0 \\
& berat & 0 & 0 & 0 & 0 \\
Tidak terinfeksi & & 67 & 20 & 2 & 0 \\
\hline Total & & 70 & 24 & 2 & 0
\end{tabular}

Dari Tabel 6 didapatkan subyek penelitian yang terinfeksi STH dan menunjukkan eosinofilia dalam pemeriksaan darahnya sebesar $57 \%(4 / 7)$. Subyek penelitian yang menunjukkan eosinofilia dan terinfeksi STH sebanyak 15,4\% (4/26).

Subyek penelitian yang terinfeksi STH dan menunjukkan tidak eosinofilia sebanyak 43\% (3/7). Subyek penelitian yang tidak menunjukkan eosinofilia dan terinfeksi STH sebanyak 4,3\% (3/70). Subyek penelitian yang tidak terinfeksi dan menunjukkan eosinofilia sebanyak $24,7 \%$ (22/89). Subyek penelitian yang menunjukkan eosinofilia dan tidak terinfeksi STH sebanyak 84,6\% (22/26). Subyek penelitian yang tidak terinfeksi STH dan menunjukkan tidak eosinofilia sebanyak $75,3 \%$ (67/89).

Hasil uji korelasi dengan Spearmen test pada penelitian ini menunjukkan kedua variabel mempunyai korelasi yang bermakna secara signifikan $(\mathrm{p}=0,032)$ dan kekuatan korelasinya sangat lemah dan arahnya positif $(\mathrm{r}=0,190)$.

Dari Tabel 1 dapat disimpulkan bahwa usia subyek penelitian berkisar antara 6 tahun hingga 80 tahun dengan jumlah yang bervariasi. Rata-rata usia adalah 37,83 tahun (6-80 tahun). Hal ini menunjukkan bahwa sebaran subyek penelitian merata di tiap usia. Dilihat dari jenis kelamin subyek penelitian, rasio subyek penelitian laki-laki : perempuan $=2: 3(40 / 56)$. Dari segi tingkat pendidikan, subyek penelitian paling banyak berpendidikan SD yaitu 36,5\%. Sedangkan pendidikan sarjana hanya $2,1 \%$. Hal ini menunjukkan tingkat pendidikan subyek penelitian di daerah ini cukup rendah. Dari segi pekerjaan, subyek penelitian paling banyak adalah swasta dan pekerjaan yang berhubungan dengan rosok. Hal ini dimungkinkan karena tempat tinggal para subyek penelitian dekat dengan TPA Putri Cempo, Surakarta.

Dari Tabel 2 dapat dilihat bahwa prevalensi infeksi STH di RW 30 sebanyak 7,29\% (7/96) yang terdiri dari infeksi hookworm yaitu 6,25\% (6/96) dan infeksi T. trichiura sebanyak 1,04\% (1/96). Tidak ditemukan infeksi A. lumbricoides dan mixed infection. Pada penelitian ini, prevalensi infeksi hookworm lebih tinggi daripada infeksi $T$. trichiura. Penelitian di Filipina, infeksi hookworm $14,7 \%$ dan infeksi $T$. trichiura sebanyak 1,7\% (Sumagaysay dan Emverda, 2010).Pada penelitian ini, infeksi T. trichiura sangat jarang, yaitu hanya satu subyek penelitian. Penelitian di Pulau Ambon, prevalensi hookworm tertinggi sebesar 4,25\% di Desa Amahusu dengan satuan lahan kambisol dari tujuh satuan lahan Pulau Ambon yang diteliti (Salakory, 2010). Dalam hal ini, mungkin tipe tanah di RW 30 adalah kambisol yaitu lempung berpasir.

Dari Tabel 3 dapat disimpulkan bahwa subyek penelitian berjenis kelamin perempuan yang terinfeksi STH lebih banyak daripada lakilaki (4:3). Hal ini mungkin disebabkan karena higiene perempuan di daerah ini kurang baik dibanding laki-laki, meskipun jumlah perempuan dibanding laki-laki tidak berbeda secara signifikan dan mempunyai kesempatan hampir sama untuk terinfeksi. Sebagian besar subyek penelitian yang menderita STH bermatapencaharian sebagai 
pemulung, yaitu sebesar 71,42\% (5/7). Pemulung merupakan pihak risiko tinggi terkena kecacingan (Ottay, 2010). Usia dari subyek penelitian yang terinfeksi hookworm adalah 50\% (3/6) berusia 3044 tahun sedangkan $50 \%$ (3/6) lainnya berusia $>50$ tahun. Infeksi hookworm puncaknya terjadi pada usia dewasa yaitu 33-44 tahun bahkan pada usia $>50$ tahun (Crompton dan Peters, 2010). Infeksi T. trichiura puncaknya pada usia 5-14 tahun, sedangkan pada penelitian ini subyek terinfeksi $T$. trichiura berusia 40 tahun. Hal ini dimungkinkan karena pengobatan terhadap infeksi cacing ini sukar dilakukan dengan cepat (Soedarto, 2011). Subyek mungkin sudah terkena infeksi saat masih kecil, infeksi ringan tidak menimbulkan gejala kemudian tidak mendapat pengobatan atau mendapat pengobatan namun kurang adekuat.

Dari Tabel 4 didapatkan intensitas infeksi STH ringan, baik pada infeksi hookworm maupun T. trichiura. Rata-ratanya 61 telur per gram tinja. Penelitian di Pulau Ambon mendapatkan hasil intensitas infeksi tunggal $T$. trichiura di lima satuan lahan dari tujuh satuan lahan adalah ringan (Salakory, 2010). Hal tersebut terjadi mungkin karena prevalensi infeksi cacing T. trichiura memang sudah rendah di Indonesia.

Dari Tabel 5 didapatkan eosinofilia 27,1\% dan tidak eosinofilia sebanyak $72,9 \%$. Eosinofilia bisa disebabkan oleh beberapa keadaan, yaitu infeksi, alergi, kanker, vaskulitis. Eosinofilia ringan dapat muncul selama penyembuhan dari infeksi bakteri, namun eosinofilia karena infeksi yang signifikan adalah dari infeksi parasit. Di seluruh dunia, sejauh ini sebab terbanyak eosinofilia adalah infeksi cacing terutama nematoda dan trematoda. Sedangkan penyebab eosinofilia tersering di negara-negara industri adalah penyakit atopik (Rothenberg dan Epstein, 1998; Ryan et al., 2002).

Penelitian ini menggunakan penghitungan cara manual dari apus darah tepi. Untuk mengetahui kesepakatan kappa dengan pemeriksaan dari laboratorium profesional, peneliti membandingkan 10 sampel. Hasilnya kesepakatan kappa sebesar 0,44, diinterpretasikan sebagai kesepakatan sedang.

Dari Tabel 6 didapatkan subyek penelitian yang terinfeksi STH dan menunjukkan eosinofilia dalam pemeriksaan darahnya sebesar $57 \%(4 / 7)$. $41,5 \%$ pasien terinfeksi cacing menunjukkan eosinofilia (Schulte et al., 2002). Terdapat peningkatan eosinofil pada infeksi cacing sebagai innate immunity (Maizels et al., 2004; Perrigoue et al., 2008). Pada infeksi hookworm, terdapat peningkatan eosinofil dalam darah (Loukas dan Prociv, 2001). Terdapat peningkatan level eosinofil sebesar $>5 \%$ pada siswa dengan STH di SDN Binjai Sumatra Utara (Arrasyid et al., 2008).

Pertahanan terhadap banyak infeksi cacing diperankan oleh aktivasi sel Th2 yang menghasilkan IgE dan aktivasi eosinofil. Struktur cacing yang dibungkus antibodi IgE dihancurkan oleh eosinofil yang membawa reseptor pada fragmen Fc. Saat eosinofil diaktivasi oleh fiksasi IgE pada Fc, eosinofil mengeluarkan granul enzim yang menghancurkan cacing. Proses ini disebut Antibody Dependent Celluler Cytotoxicity (ADCC) (Baratawidjaja dan Rengganis, 2010; Morreau dan Chauvin, 2010).

Penyebab eosinofilia memang tidak hanya infeksi STH. Eosinofilia bisa terjadi juga pada alergi, kanker, konsumsi obat dan vaskulitis (Rothenberg dan Epstein, 1998; Schulte et al., 2002). Dari anamnesis dan pemeriksaan fisik kepada para subyek penelitian yang positif infeksi STH, didapatkan hanya satu orang yang menderita Dermatitis Atopi, salah satu penyakit kulit karena alergi. Semua subyek yang positif menyangkal menderita penyakit kanker dan menyangkal sedang mengkonsumsi obat. Akan tetapi, tes yang spesifik untuk kondisi atopi (misalnya skin prick test) tidak dilakukan pada subyek penelitian.

Subyek penelitian yang menunjukkan eosinofilia dan terinfeksi STH sebanyak 15,4\% (4/26). $\quad 18,9 \%$ pasien eosinofilia terinfeksi cacing dan turis dari negara berkembang dengan eosinofilia menunjukkan peningkatan posibilitas terinfeksi cacing (Schulte et al., 2002).

Subyek penelitian yang terinfeksi STH dan menunjukkan tidak eosinofilia sebanyak 43\% (3/7). Tidak setiap infeksi STH menampakkan eosinofilia. Beberapa STH menginduksi eosinofilia hanya selama stadium invasi jaringan pada perkembangan cacing tersebut. Selain itu, eosinofilia tertinggi biasanya pada infeksi cacing yang akut (Schulte et al., 2002).

Subyek penelitian yang tidak menunjukkan eosinofilia dan terinfeksi STH sebanyak 4,3\% (3/70). Hal tersebut menggambarkan bahwa bisa saja orang yang tidak eosinofilia menderita infeksi STH.

Subyek penelitian yang tidak terinfeksi dan 
menunjukkan eosinofilia sebanyak 24,7\% (22/89). Subyek penelitian yang tidak terinfeksi STH bisa menampakkan eosinofilia disebabkan keadaan lain yang belum diketahui.

Subyek penelitian yang menunjukkan eosinofilia dan tidak terinfeksi STH sebanyak $84,6 \%(22 / 26)$. Subyek penelitian yang eosinofilia namun tidak menderita infeksi STH bisa karena gangguan lain. Dari anamnesis dan pemeriksaan fisik yang telah dilakukan kepada subyek penelitian yang tidak menderita infeksi STH, sebanyak 50\% (11/22) dimungkinkan menderita alergi yang bermanifestasi sebagai Dermatitis Atopi, Rhinitis Alergika atau Asma. Sedangkan $50 \%(11 / 22)$ belum diketahui penyebabnya. Semua subyek menyangkal menderita kanker dan mengkonsumsi obat-obatan.

Hasil uji korelasi dengan Spearman test pada penelitian ini menunjukkan kedua variabel mempunyai korelasi yang bermakna secara signifikan $(\mathrm{p}=0,032)$ dan kekuatan korelasinya sangat lemah dan arahnya positif $(\mathrm{r}=0,190)$. Penelitian di Filipina menemukan terdapat korelasi positif antara persentase hitung eosinofil dan insiden infeksi STH ( $\mathrm{n}=74$; Pearson's $\mathrm{r}=0,328 ; \mathrm{p}=0,004$ ) (Sumagaysay dan Emverda, 2010). Respon imun manusia oleh infeksi cacing tergantung jumlah cacing (parasite load) yang adekuat (Carvalho, 2006). Derajat eosinofilia dengan infeksi cacing bervariasi tergantung distribusi, maturasi, migrasi dan beratnya infeksi (Schulte et al., 2002). Cacing mengatur imunitas host sedemikian rupa sehingga tubuh host bisa untuk bertahan hidup mereka berdua (Fallon dan Mangan, 2007).

\section{SIMPULAN}

1. Prevalensi infeksi STH pada masyarakat di sekitar TPA Kelurahan Mojosongo, Kecamatan Jebres, Kota Surakarta yaitu 7,6\%, terdiri dari infeksi hookworm sebanyak 6,25\% dan infeksi T. trichiura sebanyak $1,04 \%$. Tidak ditemukan infeksi A. lumbricoides.

2. Intensitas infeksi STH pada masyarakat di sekitar TPA Kelurahan Mojosongo, Kecamatan Jebres, Kota Surakarta adalah ringan untuk infeksi hookworm maupun T. trichiura.

3. Gambaran angka eosinofil pada masyarakat di sekitar TPA Kelurahan Mojosongo,
Kecamatan Jebres, Kota Surakarta bervariasi antara $1 \%$ hingga $15 \%$. Penduduk yang tidak eosinofilia sebanyak $71,92 \%$ sedangkan $27,1 \%$ menampakkan eosinofilia.

4. Terdapat hubungan positif antara intensitas infeksi STH dengan angka eosinofil pada masyarakat di sekitar TPA Kelurahan Mojosongo, Kecamatan Jebres, Kota Surakarta dengan kekuatan sangat lemah $(\mathrm{r}=0,190$; $\mathrm{p}=0,032$ ).

\section{SARAN}

1. Untuk melihat hubungan tingkat infeksi STH dengan eosinofilia, sebaiknya di lokasi yang prevalensi infeksi STH tinggi dan lebih bervariasi.

2. Saran untuk klinisi, jika menemukan kasus eosinofilia sebaiknya mempertimbangkan adanya infeksi cacing selain penyakit lain.

3. Saran untuk masyarakat, jika ada eosinofilia sebaiknya curiga adanya infeksi cacing.

\section{UCAPAN TERIMAKASIH}

Terimakasih kepada Universitas Muhammadiyah Surakarta atas dana yang telah diberikan.

\section{DAFTAR PUSTAKA}

Arrasyid, N.K., Yoan, C.P., Lambok, S. 2008.Eosinophil profile of elementary student, caused by soil transmitted helmints infection at SD Negeri 026559 Binjai, Sumatra Utara.

Baratawidjaja, K.G., Rengganis, I. 2010. Imunologi Infeksi. Dalam Imunologi Dasar. Ed 9. Jakarta : Balai Penerbit FKUI.

Carvalho, E.M., Bastos, L.S., Araujo, M.I. 2006. Worms and allergy. Parasite immunol. 28(10):52534.

Crompton, D., Peters, P. 2010.First WHO report on neglected tropical diseases : Working to overcome the global impact of neglected tropical diseases [online]. Available : www. who.int/neglected_diseases/2010report/ [5 Mei 2013].

Depkes RI. 2006.Pedoman pengendalian cacingan [online]. Available: www.hukor.depkes. go.id [23 Pebruari 2013]. 
Ehrhardt, S., Burchard, G.D. 2008.Eosinophilia in returning travellers and migrants. Dtsch Arztebl Int. 105 (46):801-7.

Fallon, P.G., Mangan, N.E. 2007. Suppression of Th2type allergic reaction by helminth infection. Nat Rev Immunol7(3): 220-30.

Janeway, C.A., Travers, P., Walport, M., Shlomchik, M. 2005. The immune system in health and disease. Dalam Immunobiology. 6th edition. New York : Garland Science Publishing.

Loukas, A., Prociv, P. 2001.Immune responses to hookworm infections.Clin Microbiol Rev.2001;14: 689-703.

Lwanga, S.K, Lemeshow, S. 1991.Sample size determination in health studies, a practical manual. Geneva: WHO.

Maizels, R.M, Balic, A., Gomez-Escobar, N., Nair, M., Taylor, M.D., Allen, J.E. 2004. Helminth parasites-master of regulation. Immunol Rev. 201:89-116.

Morreau, E., Chauvin, A. 2010. Immunity against helminths : Interactions with the host and the intercurrent infections. J Biomed Biotechnol. ID: 428593

Ottay, R.I. 2010. Hubungan antara perilaku pemulung dengan kejadian penyakit cacingan di tempat pembuangan akhir sampah Sumampo Kota Manado. Jurnal Biomedik Vol. 2 No. 1 Maret 2010. Hal 38-43

Perrigoue, J.G, Marshall, F.A, Artis, D. On the hunt for helminths : innate immune cells in the recognition and response to helminth parasites. Cell. Microbiol. 2008;10(9), 1757-1764.
Rothenberg, M.A., Epstein, F.H (editor). 1998. Mechanisms of disease : Eosinophilia. N Engl J Med.338(22):1592-1600.

Rusmartini, T. 2009.Penyakit oleh nematoda usus. Dalam Parasitologi Kedokteran Ditinjau dari Organ Tubuh yang Diserang. Diedit oleh Djaenudin N. dan Ridad A. Jakarta : EGC.

Ryan, E.T., Wilson, M.E., Kain, K.C. 2002. Ilness after international travel. N Engl J Med.347:50516.

Salakory, M. 2010. Beberapa aspek ekoepidemiologi dan dinamika populasi geohelminths serta prevalensi dan distribusinya di perdesaan Pulau Ambon Maluku. Yogyakarta : Program Doktor IKK FK UGM.

Schulte, C., Krebs, B., Jelinek, T., Nothdurft, H.D., von Sonnenburg, F., Loescher, T. 2002. Diagnostic significance of blood eosinophilia in returning travellers. Clin Infect Dis.34:407-411.

Soedarto. 2011. Nematoda. DalamBuku Ajar Parasitologi Kedokteran. Jakarta : CV Sagung Seto.

Sumagaysay, J.B., Emverda, F.M. 2010.Eosinophilia and incidence of soil-transmitted helminthic infections of Secondary students of an indigenous school. Asian journal of health (e-journal). 1(1):172-184.

Supali, T., Margono, S.S., Abidin, S.A. 2011. Nematoda usus. Dalam Buku Ajar Parasitologi Kedokteran. Ed 4. Diedit oleh Inge S, Is Suhariah I, Pudji KS, Saleha S. Jakarta : Badan Penerbit FKUI 